\title{
Proceeding
}

Supplementary Issue: Winter Conferences of Sports Science. International Conference on Psychology of Education Sciences and Lifestyle.

\section{Identifying the underlying factors affecting the development of participation of student sport in Iran}

\author{
MEHDI NASIRI KHOUZANI ${ }^{1}$, SHAHRAM AROUFZAD 23 , MOHAMMAD ALI NADI ${ }^{3}$ \\ ${ }^{1}$ Faculty of Sport Sciences, Isfahan (Khorasgan) Branch, Islamic Azad University, Isfahan, Iran \\ ${ }^{2}$ Department of Sport Management, Management and Planning Tendency, Department of Educational \\ Sciences, Farhangian University, Isfahan, Iran \\ ${ }^{3}$ Department of Educational Management, Faculty of Educational Sciences and Psychology, Isfahan \\ (Khorasgan) Branch, Islamic Azad University, Isfahan, Iran
}

\begin{abstract}
The purpose of this study was to identify the underlying factors that have an effect on the development of participation of student sport in Iran. The research method is qualitative and with Grounded Theory approach and it is inductive and exploratory. The research area consisted of 20 experts in sport management and student sport. The sampling method used a snowball based on the theoretical approach and continued until the categories reached theoretical saturation. The research tool was in-depth and exploratory semi-structured interviews. The validity of the findings was determined by matching methods by peer members and experimental interviews. Data were analysed using open, axial and selective coding using MAXQDA 2018 software. According to the results of the research, the underlying factors that have an effect on the development of participation of student sport were identified and extracted in nine main categories including community dynamism, synergy, financing, provide education, program-oriented activities, social capital, promoting participation culture, role-playing of managers, extracurricular activities in the field of student sport. Thus, student sport policymakers can use the concepts, components, and categories identified in their future plans to promote the status of school sports, especially in the international arena, and promote community health and to have a healthy and dynamic lifestyle, as well as the synergy of organizations and institutions to promote student sport.
\end{abstract}

Keywords: Participation; Student sport; Development; Health; Dynamism.

Cite this article as:

Khouzani, M.N., Aroufzad, S., \& Nadi, M.A. (2020). Identifying the underlying factors affecting the development of participation of student sport in Iran. Journal of Human Sport and Exercise, 15(2proc), S379-S392. doi:https://doi.org/10.14198/ihse.2020.15.Proc2.29

Corresponding author. Department of Sport Management, Management and Planning Tendency, Department of Educational Sciences, Farhangian University, Isfahan, Iran.

E-mail: aroufzad@gmail.com

Supplementary Issue: Winter Conferences of Sports Science. International Conference on Psychology of Education Sciences and Lifestyle.

JOURNAL OF HUMAN SPORT \& EXERCISE ISSN 1988-5202

(C) Faculty of Education. University of Alicante

doi:10.14198/jhse.2020.15.Proc2.29 


\section{INTRODUCTION}

Educating healthy, intelligent, and creative individuals are the ideal goal of all human societies for a secure future so that achieving this stage is one of the goals of statesmen and people in every society (Keshavarz et al., 2013). Of course, young people are considered as one of the main human resources of any society and their health is closely linked to the establishment of health in society, so that healthy youth are at the heart of community development and have a decisive influence on the future development and progress of society (Khoshfar et al., 2014).Therefore, progress, development, and excellence in any society can be tracked when community leaders, planners, policymakers place main and primary attention on children and adolescents at the forefront of their work, In between, health as one of the divine blessings and doing physical activity and mobility is one of the ways to provide human health, especially children as a vulnerable group of society (Izadi et al., 2011).

In the same vein, the Education and Training Organization also in the fast-paced path of the fundamental evolution of the education system, considers physical education and sport as a necessity and strives to bring students to the summit of physical and mental health (Rezaian, 2005). As most of the educational goals can be achieved through the participation of students in sports and motor activities and physical education as one of the branches of education plays an important role in the process of physical and mental development of learners (Javadipour, 2006). Also sport participation promotes mental health and prevents mental illness (Isabelle Doré et al .,2019). And on this basis, it should not be thought that physical education is worthless and entertaining and merely provides entertainment for children and young people; on the contrary, it should be an important part of life's activities. Concepts such as health, hygiene, personal and social development, and mental health are closely related to physical education and exercise (Namazizadeh \& Salahshour, 2015).Nowadays, physical education is considered as the art and science of human movement in primary schools of the world which response to why and how the body moves. It teaches the child it's physiological, psychological, and social causes and, through the movement achieve self-expression, creativity, development of self-love, registration, and reach and a better understanding of his or her physical dimension (Diorra and Challers, 1995). Physical activity, therefore, contributes to physiological and mental health and has positive effects on youth health outcomes including aerobic and anaerobic capacity, cardiopulmonary system, respiratory system, body composition and muscular health (MalekoOghlou, 2015).Physical education as an educational process includes acquiring and processing motor developmental skills and maintaining physical fitness for health, gaining scientific knowledge about physical activities and exercise, and developing a positive image and mentality of physical activities as a means of improving physical activity and performance that has an important role to play in the growth and excellence of individuals. For this science, the goals have been stated that include the desired signs, intentions, and results obtained from participation in physical education and exercise programs. These goals are related to the needs, experiences, and interests of individuals and determine the goals and direction of the programs. Given the importance and development of the field of physical education and sport, its goals are not limited to specific populations but extend to all populations (Fathi, 2003). Since students and adolescents form a large part of society, their establishment and vitality guarantee the future economic and social health of the country. Therefore, physical education and regular exercise in schools and academies are one of the keys and effective tools of growth of the next generation and in order to achieve this goal in schools, sport and physical education lesson is the only lesson that enhances all human dimensions including physical and mental, moral, motor and social aspects through physical activities (Khalaji, 2008). As in recent years, one of the most important messages of public health has been sport participation and physical activity on a regular basis (Mills, Dudley, and Collins, 2019). 
However, the social-public health influenced by life in today's industrial world is faced with many challenges; as this type of life takes the rapid initiative to move from people and has made him in movement poverty and this movement poverty has caused many physical, psychological and social problems for them. For this reason, organizations and social institutions place great importance on health and physical activity in their programs to create social vitality. In the meantime, sport as a strategic solution and sport participation as an inexpensive and refreshing tool can be optimally used to solve the problem of movement poverty and social well-being (Javadipour and Sami' Nia, 2013). Of course, participation is an essential part of human growth and development of self-confidence, initiative, pride, activity, responsibility and social cooperation. Without such development and evolution within the people, efforts to eliminate poverty and underdevelopment, if not impossible, would at least face many problems (Burkley, 1996). Therefore, participation is one of the phenomena that has long existed and has always been linked to human life. The need for collective and group life is the existence of cooperation, assistance, and participation that has shaped in different ways according to social conditions in their particular time and place (Nava bakhsh and Esmi, 2012). Therefore, participation attraction and engagement in the field of student sport are important, as US high school athletic participation has beneficial effects on future education, labour market and health outcomes (Ransom, 2018). Therefore, one of the most important institutions that provide the background for current and future student activities is education (Alizadeh et al., 2016), and extracurricular activities outside the main classroom lead to the learning and experience of students in the combination activities includes physical, artistic and professional in school and community and links participation with a broad set of scientific, psychological and social outcomes (Gilmet et al., 2019:Shayakhmetova\&Chaklikova, 2018).

Today, sport and its various dimensions are considered as an important topic in various circles and are used as an effective tool and unique phenomenon to create a vibrant and dynamic society and to overcome many social, cultural and even economic and political crises, has revealed its many applications. (Salimi, 2017). And the relationship of sport to cultural, social, political, and economic phenomena indicates the importance of this phenomenon and its role in national development programs of countries and at a glance, the development and progress of sport in any country is closely linked to its authority and power (Banar et al, 2018). It seems that having concern integrates the explaining of comprehensive views on development and health, social, economic, and environmental considerations. These considerations are also interlinked with common principles and processes such as commitment to equality and social justice, sustainability, intergroup action, and public participation (Lawrence, 2015).In line participation, Asefei and Amouzadeh (2017) conducted research and stated in their research that the role of parent support, the model role of friends and role of teacher interaction had the highest correlation with participation in sport and level of physical activity of adolescents and teachers have the most effect on adolescent participation in physical activity and exercise, and after that, they were friends, peers, and parents, respectively. Also, Monafi et al. (2015) conducted a study to evaluate the effect of infrastructure factor and management on the development of student participation in public universities in Iran and stated that university sport management is a precedent for hardware and software infrastructure and with proper management intervention, it can promote student participation. Boykel et al. (2016) stated in a study that organized sports in American schools play an important role in students' educational and social experiences, and the findings showed that students who volunteer regularly (at least 1-2 times a week) exercising in schools than in those who do not participate in any school sport will provide them with a greater understanding of school safety and family, teacher, and community support and the results of this study provide guidance for parents, educators, and policymakers. Also, Howard et al. (2018) conducted a study on self-efficacy and sport participation in Australian children. The researchers examined whether participation in childhood exercise (4-5 years) could change children's self-efficacy. And the results showed that up to two years after the start of exercise, there would be changes and that children who participated in individual sports were significantly more self-efficacious than those who 
did not participate, and in addition, children with weak self-efficacy are less likely to participate in sport, As a result, they suggested participating in sports to improve children's self-efficacy. With these interpretations, great and positive steps should be taken for the development of student participation in the country in terms of culture and education of community members, including sports managers, teachers, parents, and students. To achieve these goals, there should be some planning in the interested organizations of the student sports field that is consistent with what is being taught to the needs of the student sports community. With these interpretations, the study of the factors that have effect on student participation in the progress and development of student sport in Iran can be effective and applicable, and attracting infrastructures and resources, and providing mobility and dynamism in students and community members, and to explore the scientific underpinnings of the field (Alkhateeb, 2019).

\section{METHODOLOGY}

The research method in this study is qualitative, with the Grounded Theory approach and is inductive and exploratory. To apply the grounded theory method, semi-structured interviews were used to identify the underlying factors affecting the development of participation of student sport in Iran. The scope of the present study were identified some of the experts and informants in the field of student sports such as general manager and deputies of physical education and health, heads of offices of physical education and sport activities, ministries and administrations of provinces, expert student sport officials, president and officials of student sport federation and physical education specialists with a tendency for sport management with a specialized doctorate degree.Sampling was done by the snowball method and referring to other informants. This sampling and interviewing process continued until the process of analysis and discovery reached theoretical saturation. In the data analysis, at first, open coding, then axial coding and then Strauss and Corbin selective coding by using MAXQDA 2018 software was performed. The researcher first wrote the interviews in conversational text and during the open coding phase, the data were analysed line by line and the intended concepts identified and the features and dimensions related to the interviews were extracted. In the axial coding step, discovered components were linked to each other at the level of features and dimensions, and in selective coding, components were integrated to form a larger theoretical arrangement and eventually the main categories. Contextual factors (substrate and effective Factors on strategies), finally, by performing selective coding, the research theory about identifying the factors influencing the development of participation of Iranian student sport has been narrated. To evaluate the validity of this research, the final report of the process of data analysis and the resulting categories was transferred to the interviewees after being implemented by the researcher to confirm the validity of the researcher's perceptions. The coding process was also reviewed by three experts who were not members of the interview group and their suggestions were used. In order to evaluate the reliability of the qualitative tool, the researcher conducted two experimental interviews and after analysing the results and then comparing them with the research objectives and questions, modifications were made to the questions and prioritization of the questions to increase the accuracy of the research tool. In the meantime, the Strauss and Corbin process of qualitative research (2008) has been depicted in Figure (1). 


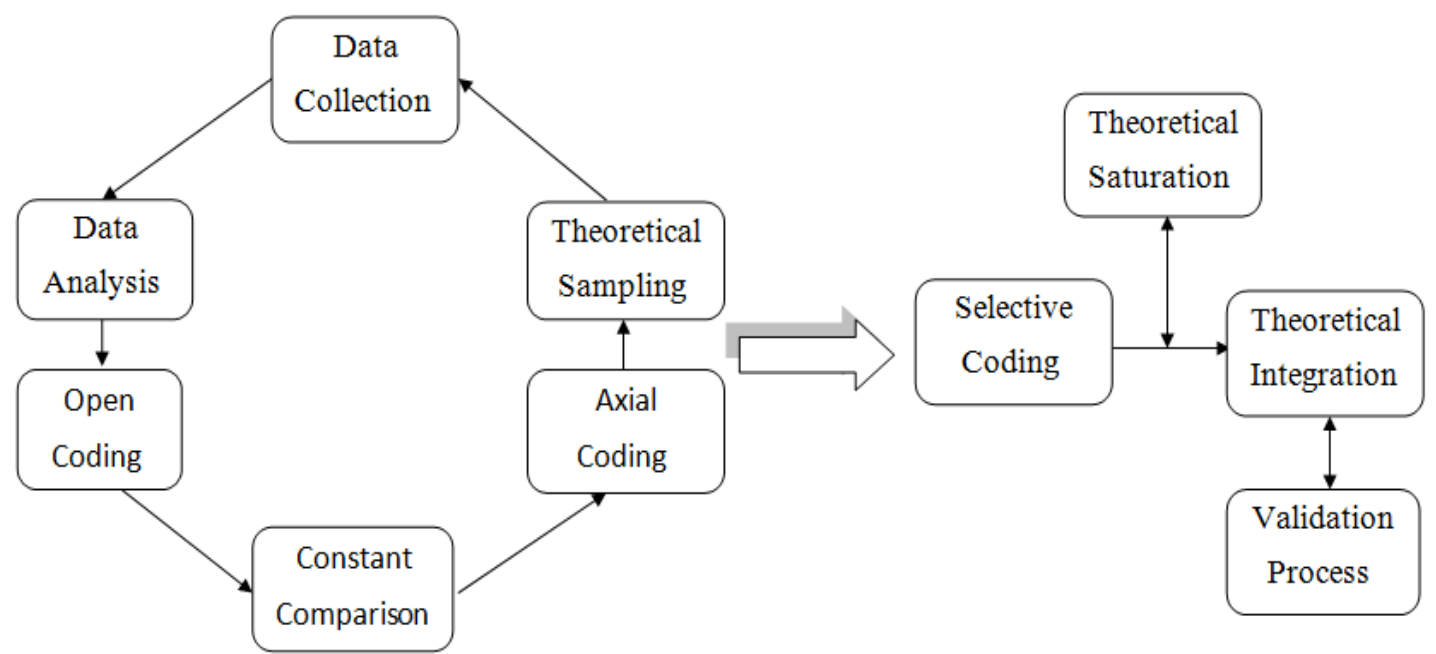

Figure 1. Steps of grounded theory based on Strauss. Source: Based on Strauss \& Corbin (2008).

\section{RESULTS}

The demographic characteristics and frequency distribution of experts, elites, and stakeholders of the near and far environment of the student sports field of the present study have been presented in Table 1 . As the table shows, the total number of interviewees has been 20 people that all of whom are college-educated and most have more than 10 years of administrative experience.

Table 1. Demographic characteristics and frequency distribution of interviewees.

\begin{tabular}{|l|c|c|c|c|c|c|c|c|}
\hline \multirow{2}{*}{ Index } & \multicolumn{3}{|c|}{ Age } & \multicolumn{3}{c|}{ Degree of education } & \multicolumn{2}{c|}{$\begin{array}{c}\text { Administrative } \\
\text { background }\end{array}$} \\
\cline { 2 - 11 } & $30-40$ & $41-50$ & $51-60$ & $\begin{array}{c}\text { Bachelor's } \\
\text { Degree }\end{array}$ & $\begin{array}{c}\text { Master's } \\
\text { Degree }\end{array}$ & Ph.D. & $1-10$ & $11-20$ \\
\hline Frequency & 1 & 14 & 5 & 1 & 5 & 14 & 5 & 10 \\
\hline Frequency percentage & 5 & 70 & 25 & 5 & 25 & 70 & 25 & 50 \\
\hline $\begin{array}{l}\text { Cumulative frequency } \\
\text { percentage }\end{array}$ & 5 & 75 & 100 & 5 & 30 & 100 & 25 & 75 \\
\hline
\end{tabular}

Table 2. Codes obtained from qualitative analysis of data in open, axial and selective coding of participation of student sport.

\begin{tabular}{|l|l|l|}
\hline Open coding (concepts) & $\begin{array}{l}\text { Axial Coding } \\
\text { (Components) }\end{array}$ & $\begin{array}{l}\text { Selective } \\
\text { coding } \\
\text { (Categories) }\end{array}$ \\
\hline $\begin{array}{l}\text { Create a sense of sportsmanship; creating a need for family } \\
\text { dynamism by principals and teachers; promoting social vitality; } \\
\text { rebuilding and filling leisure time with sports; engaging students, } \\
\text { family to sports }\end{array}$ & $\begin{array}{l}\text { Create a sense } \\
\text { of sportsmanship }\end{array}$ & $\begin{array}{l}\text { Community } \\
\text { dynamism }\end{array}$ \\
\hline $\begin{array}{l}\text { Low per capita study of public sport; increased per capita student } \\
\text { activity; the increased proportion of physical education classes; } \\
\text { couple or parent and child exercise plan; Promoting physical, } \\
\text { mental health; Raising general family culture for sedentary reform }\end{array}$ & $\begin{array}{l}\text { Activity per } \\
\text { capita }\end{array}$ & \\
\hline
\end{tabular}




\begin{tabular}{|c|c|c|}
\hline $\begin{array}{l}\text { Establishing a student health safety executive task force; } \\
\text { Influencing student sports programs on health promotion; } \\
\text { Instituting sports hygiene and health among students; Choosing a } \\
\text { hero as a health ambassador; the health of the environment } \\
\text { around the current and future generations, Transfer of } \\
\text { environmental information through sport activities and ensuring } \\
\text { community biological health; the role of exercise in reducing } \\
\text { treatment and drug costs and increasing life expectancy }\end{array}$ & $\begin{array}{l}\text { Promote health } \\
\text { and hygiene }\end{array}$ & \\
\hline $\begin{array}{l}\text { Decision Making and Participation Decision Making; Using Your } \\
\text { Predictive Experiences and Opinions; Holding a Roundtable on } \\
\text { Sport and Health with Exarch and Governor Host; Decision- } \\
\text { Making Research; Consulting with the Director of Renovation by } \\
\text { Experts }\end{array}$ & $\begin{array}{l}\text { Participatory } \\
\text { decision making }\end{array}$ & \multirow[t]{4}{*}{ Synergistic } \\
\hline $\begin{array}{l}\text { Maximizing efficiency and effectiveness; identifying and utilizing } \\
\text { the capabilities of other machines and human resources; } \\
\text { achieving a common goal by involving multiple people or } \\
\text { organizations with teamwork; modelling Kaizen management for } \\
\text { continuous and gradual improvement of student sports; promoting } \\
\text { economic thinking and a culture of savings In schools, using the } \\
\text { power of state-owned companies to execute projects }\end{array}$ & Efficiency & \\
\hline $\begin{array}{l}\text { Interaction of student sport with sports board, neighbourhood } \\
\text { sports centre, and health areas; constructive and profitable } \\
\text { interactions with competent bodies; objective and tangible } \\
\text { interactions with goodwill officials; Cultural-Social Interaction } \\
\text { between Ministry of Culture and Islamic Guidance and Education } \\
\text { to Prevent Students' Social Injuries, Communications for the } \\
\text { benefit of the organization; influence of the Higher Education } \\
\text { Council on other organs }\end{array}$ & $\begin{array}{l}\text { Communications } \\
\text { and Interactions }\end{array}$ & \\
\hline $\begin{array}{l}\text { Creating delegation of authority in different sectors; Benefiting the } \\
\text { ability and potential of schools; Dividing duties into stakeholders } \\
\text { organizations; Participating and communicating within and outside } \\
\text { the organization according to law; Partnership-driven of student } \\
\text { sport activities; decentralization }\end{array}$ & $\begin{array}{l}\text { Participation } \\
\text { centred activities }\end{array}$ & \\
\hline $\begin{array}{l}\text { Reengineering for outsourcing; the importance of mutual benefit } \\
\text { and win-win interaction; creating a joint chapter on the potential of } \\
\text { sponsors, beneficiaries, parents and other devices to fund and } \\
\text { infrastructure; ensuring return on investment and low-risk } \\
\text { profitability to the investor, The high capacity of schools to accept } \\
\text { sponsors ؛ The role of internal, external motivation and } \\
\text { encouragement ؛ Providing a platform for broadcasting student } \\
\text { sporting events and making student sport attractive to sponsors; } \\
\text { Facilitating and modifying sponsorship rules }\end{array}$ & Sponsors & \multirow[t]{2}{*}{ Financing } \\
\hline $\begin{array}{l}\text { Facilitating affairs and communication with the beneficiaries; } \\
\text { Signing a Memorandum of Understanding for Free using of } \\
\text { Students from beneficent made sport places; Informing the } \\
\text { beneficiaries and supervising them on the stages of the } \\
\text { implementation of the beneficent made projects; Creating an }\end{array}$ & $\begin{array}{l}\text { Attracting } \\
\text { Beneficiaries }\end{array}$ & \\
\hline
\end{tabular}




\begin{tabular}{|c|c|c|}
\hline $\begin{array}{l}\text { understanding and forming an attitude and belief in charity; } \\
\text { Holding meetings and explaining incentives and dignity and } \\
\text { respect policies for charities; Completion of beneficent made } \\
\text { projects by renovation department }\end{array}$ & & \\
\hline $\begin{array}{l}\text { Earning money with sports associations; lifting business and } \\
\text { advertising restrictions for school principals; Proper advertising in } \\
\text { the field of participation; opportunity for revenue generation and } \\
\text { growth of sports economics with educational sports; Identify the } \\
\text { restrictions, rules, and requirements for participation by managers }\end{array}$ & Marketing & \\
\hline $\begin{array}{l}\text { Enhancing student sport place per capita; Creating appropriate } \\
\text { sporting space in the office of reconstruction proceedings; } \\
\text { Dedicated to the construction and equipping of student sport with } \\
\text { the private sector; Observing environmental attachments In } \\
\text { locating and building places, Standardize the student sport } \\
\text { environment }\end{array}$ & $\begin{array}{l}\text { Sports space per } \\
\text { capita }\end{array}$ & \\
\hline $\begin{array}{l}\text { Increasing sport's share of GDP; increasing student sport per } \\
\text { capita; Credit limitations and education budgets; reliance on } \\
\text { government credits; examining organization and community } \\
\text { needs; changing organization and budgeting views of schools; } \\
\text { Creating a sense of athleticism leads to increased cost (Corrective } \\
\text { budget by comparing actual spending with approved budget) and } \\
\text { the direct effect on the sport economy }\end{array}$ & $\begin{array}{l}\text { Government } \\
\text { financial credits }\end{array}$ & \\
\hline $\begin{array}{l}\text { Creating strong macro-legal infrastructures of the community; } \\
\text { Effective role of supportive laws and executive regulations to } \\
\text { attract participation; Developing laws and regulations and adapting } \\
\text { them to other sectors; Create good higher national rules }\end{array}$ & $\begin{array}{l}\text { Legal } \\
\text { infrastructure }\end{array}$ & \\
\hline $\begin{array}{l}\text { Defining the structure of student sport sustainability for sponsors; } \\
\text { Developing a three-pronged model: contextual, structural and } \\
\text { human factors; refining and modifying the management structure } \\
\text { of student sport; providing a short, easy and flexible process of } \\
\text { participation; providing new and up to date guidelines, codes of } \\
\text { practice and style sheets }\end{array}$ & Flexible structure & \\
\hline $\begin{array}{l}\text { Officials and benefactors awareness of the purpose of educational } \\
\text { sport; understanding the importance of sport in the educational } \\
\text { system; transferring environmental information in the sports } \\
\text { environment; informing and promoting culture through educational } \\
\text { programs; Putting sports in students' intellectual and educational } \\
\text { bases; promoting economic thinking and a culture of saving }\end{array}$ & Notices & Provide training \\
\hline $\begin{array}{l}\text { Environmental Education in Virtual, Social and Organizational } \\
\text { Networks; The Role of Broadcasting in Advertising and Informing } \\
\text { Student Activities; The Effective Role of Education and Sport } \\
\text { Network }\end{array}$ & $\begin{array}{l}\text { The Role of the } \\
\text { Media }\end{array}$ & \\
\hline $\begin{array}{l}\text { Educating students in Iranian, Islamic standards with student } \\
\text { sport; Educating and growing in the positive aspects of life; Getting } \\
\text { to know the discipline and respect; Communication with peers in } \\
\text { the sports environment; Learning orbital law and orbital ethics in } \\
\text { the sport environment }\end{array}$ & $\begin{array}{l}\text { Iranian, Islamic } \\
\text { education }\end{array}$ & \\
\hline
\end{tabular}




\begin{tabular}{|c|c|c|}
\hline $\begin{array}{l}\text { Participation training in speech, writing, electronic, virtual, and } \\
\text { holding activities; learning and awareness of community rules in } \\
\text { the form of games and sports; learning participation at an early age }\end{array}$ & $\begin{array}{l}\text { Diversity of } \\
\text { education }\end{array}$ & \\
\hline $\begin{array}{l}\text { Defining Vision and Mission for Beneficiaries; Aligning Plans, } \\
\text { Goals, and Vision of Educational Sports with Sustainable } \\
\text { Development Plans; Providing Long Term Plans, Policies, and Big } \\
\text { Strategies for Development of Student Sport }\end{array}$ & $\begin{array}{l}\text { Vision and } \\
\text { Policies }\end{array}$ & \multirow[t]{8}{*}{$\begin{array}{l}\text { Program-centred } \\
\text { making of } \\
\text { activities }\end{array}$} \\
\hline $\begin{array}{l}\text { Creating long-term, sustainable planning with shared interests; } \\
\text { Providing 5-year continuous and strategic plans under the national } \\
\text { development system for participation; Providing attitudinal } \\
\text { strategies by executives; Providing sector development strategy } \\
\text { with sport; Strategic approach to student sport, Ideal development } \\
\text { with presenting strategies }\end{array}$ & $\begin{array}{l}\text { Develop a } \\
\text { strategic plan }\end{array}$ & \\
\hline $\begin{array}{l}\text { Providing students' sporting needs based on the Maslow model; } \\
\text { Modelling sports principals and teachers from successful and light- } \\
\text { skinned sports schools in education; modelling of principals, } \\
\text { teachers, and coaches for student education }\end{array}$ & Patterning & \\
\hline $\begin{array}{l}\text { Programming activities and goals; Providing hardware, software } \\
\text { and anthropomorphic applications; Enabling participation } \\
\text { programs; Coordinating development plans with the interests of } \\
\text { individuals and organizations; Accompanying the private sector } \\
\text { with key physical education lesson programs to provide the } \\
\text { modern equipment needed }\end{array}$ & Applications & \\
\hline $\begin{array}{l}\text { Achieving common goals and objectives with social solidarity; Unit } \\
\text { management in festivals and competitions; Developing a } \\
\text { systematic of sports trusteeship and having a unified code of } \\
\text { procedure for all stakeholders organs in sport field }\end{array}$ & $\begin{array}{l}\text { Developing a } \\
\text { unique ruling }\end{array}$ & \\
\hline $\begin{array}{l}\text { Consultation with scientific communities; Promoting depth } \\
\text { tendency and modernity; Forming a research and development } \\
\text { group; A study of the fundamental transformation document by } \\
\text { students in the field of student sport }\end{array}$ & Develop an idea & \\
\hline $\begin{array}{l}\text { Investigating the public and functional environment within and } \\
\text { outside the organization; preparing and analysing environmental } \\
\text { conditions, opportunities, threats and strengths, and weaknesses } \\
\text { of the student sport field }\end{array}$ & Preparation & \\
\hline $\begin{array}{l}\text { Scientific and specialized activities; Scientific, educational and } \\
\text { sport dynamism of schools; Promotion of sports science in the } \\
\text { educational system; Theoretical teaching of sports to students } \\
\text { Content review of physical education lesson }\end{array}$ & $\begin{array}{l}\text { Specialization } \\
\text { and scientific } \\
\text { activities }\end{array}$ & \\
\hline $\begin{array}{l}\text { Safe place of education for families; Family and school, the most } \\
\text { important social institutions; Student representing a family as the } \\
\text { target community; Socialization of sport; Increasing social capitals }\end{array}$ & $\begin{array}{l}\text { Social } \\
\text { organizations }\end{array}$ & \multirow[t]{2}{*}{ Social capitals } \\
\hline $\begin{array}{l}\text { Utilizing the capacities of associations, councils, assemblies, and } \\
\text { student organizations; acquainting with social and life skills } \\
\text { through student organizations; forming a golden age and student }\end{array}$ & Student-centred & \\
\hline
\end{tabular}




\begin{tabular}{|c|c|c|}
\hline $\begin{array}{l}\text { personality at school; changing student worldviews and attitudes; } \\
\text { the student-centred making of sports activities field } \\
\text { Exercise board, active part of NGOs; use of NGO comments in } \\
\text { meetings; volunteer movement, free helper; financial, spiritual, and } \\
\text { voluntary participation underlie student sport growth; Benefit from } \\
\text { volunteer and benevolent forces and other entities in legal } \\
\text { processes }\end{array}$ & Volunteer Forces & \\
\hline $\begin{array}{l}\text { The Role of Families' Beliefs and Cultures in Partnership, the } \\
\text { Effective Role of the Sport Management System's Viewpoints and } \\
\text { Beliefs, Community Beliefs about Sport, the effect of Participation } \\
\text { on Personality Development and Deepening Beliefs }\end{array}$ & Beliefs & \multirow[t]{5}{*}{$\begin{array}{l}\text { Promoting a } \\
\text { culture of } \\
\text { participation }\end{array}$} \\
\hline $\begin{array}{l}\text { Limitation of Islamic Community in Adoption of Some Sports; } \\
\text { Ethics-centre Making of Student Sport; Existence of Islamic, } \\
\text { Cultural, Iranian Customs in Fundamental Transformation } \\
\text { Document }\end{array}$ & Customs & \\
\hline $\begin{array}{l}\text { Promoting Social Participation Behaviour with Sport; Forming } \\
\text { Student Social Behaviour in the Sport Environment; Observing } \\
\text { People's Rights and Making Community Peace with Partnership; } \\
\text { The Influence of Social Personality appearances on Individual } \\
\text { Behaviour, Socialize }\end{array}$ & Social behaviour & \\
\hline $\begin{array}{l}\text { Participation Dependence on Behaviour and Culture and Values; } \\
\text { Promoting Valuation Culture in Student Sport Participation, } \\
\text { Increasing social and individual values through sport }\end{array}$ & Social values & \\
\hline $\begin{array}{l}\text { Social growth and development of citizenship culture; Influencing } \\
\text { teachers' behaviour and thoughts on students; Defining and } \\
\text { institutionalizing sports culture amongst officials and families and } \\
\text { students; participation, the saviour of the culture of the country; } \\
\text { cultivating of participation by trustees }\end{array}$ & $\begin{array}{l}\text { Promoting a } \\
\text { culture of } \\
\text { participation }\end{array}$ & \\
\hline $\begin{array}{l}\text { The Effect of Communication Skills, Creativity, Compassion, } \\
\text { Social Reasoning, Risk-taking, Social Intelligence, Knowledge, } \\
\text { Flexible Personality, Patience in Managers' Partnership }\end{array}$ & $\begin{array}{l}\text { Collaborative } \\
\text { Managers }\end{array}$ & \multirow[t]{4}{*}{$\begin{array}{l}\text { The role of } \\
\text { managers }\end{array}$} \\
\hline $\begin{array}{l}\text { Using meritocracy factor in executives and encouraging and } \\
\text { promoting their careers; Knowledge of legal processes by } \\
\text { competent managers; The role of meritocracy and motivation in } \\
\text { promoting sport and participation }\end{array}$ & Meritocracy & \\
\hline $\begin{array}{l}\text { The Role of Managers based on Law and Fundamental } \\
\text { Transformation Document; The Role of Different Institutions in the } \\
\text { Fundamental Transformation Document, Evaluation of Economic } \\
\text { and Financial Policies Based on Fundamental Transformation } \\
\text { Document; Implementation of Intellectual, Physical and Biological } \\
\text { Development Discussion in Fundamental Transformation } \\
\text { Document }\end{array}$ & $\begin{array}{l}\text { Fundamental } \\
\text { Transformation } \\
\text { Document }\end{array}$ & \\
\hline $\begin{array}{l}\text { Effective role of local managers in attracting participation, Native } \\
\text { managers' awareness of the complexes, infrastructures, } \\
\text { ethnicities, cultures, and customs of the region }\end{array}$ & Native managers & \\
\hline
\end{tabular}




\begin{tabular}{|l|l|l|}
\hline $\begin{array}{l}\text { student sport, the foundation, and basis of the country's sport; } \\
\text { integrating the whole sport system with educational sport; the } \\
\text { development and facilitation of student sport; the educational } \\
\text { mission of Education, educational sport as part of the education } \\
\text { system }\end{array}$ & $\begin{array}{l}\text { Facilate } \\
\text { sustainable } \\
\text { student sport }\end{array}$ & $\begin{array}{l}\text { Extracurricular } \\
\text { activities }\end{array}$ \\
\hline $\begin{array}{l}\text { Extracurricular activities under the supervision of student sports } \\
\text { board; the role of physical education deputy and teacher } \\
\text { specialization in the lesson and extracurricular activities; high } \\
\text { capacity of participation in extracurricular of schools and leisure } \\
\text { participations; implementing leisure extracurricular activities of } \\
\text { physical education lesson; Creating clubs and student sports }\end{array}$ & \\
leagues in various & \\
\hline $\begin{array}{l}\text { Identifying students' interests and talents with educational sport; } \\
\text { establish a talent identification contract between schools, families, } \\
\text { and clubs; developing physical, logical, and intellectual talents; } \\
\text { prophecy of the championship and talent identification of ministry } \\
\text { of sports and its use of schools' potential, Valuing the Olympics for } \\
\text { top and in-school talent and festivals }\end{array}$ & \\
\hline
\end{tabular}

Based on the findings of Table 2 and using the semi-structured interview method, the information obtained from the views and opinions of the experts were summarized as intended meanings of research. Interviews were analysed using MAXQDA2018 software and at first, the practical concepts were collected as open codes and after open coding, to identify the similarities and differences in the listing of the extracted content from the interviews, the axial coding process was used and the axial codes were selected by integrating some of the concepts and codes of the previous step.In the final coding step, the axial codes in the previous step were integrated in terms of integrity and holism, comprehensiveness and applicability of each concept, in terms of semantic and content relationship and then selectively extracted to complete the three-part coding process. At the end of this step, the following chart was drawn as the underlying factors affecting the development of participation of student sport in Iran (Figure 2).

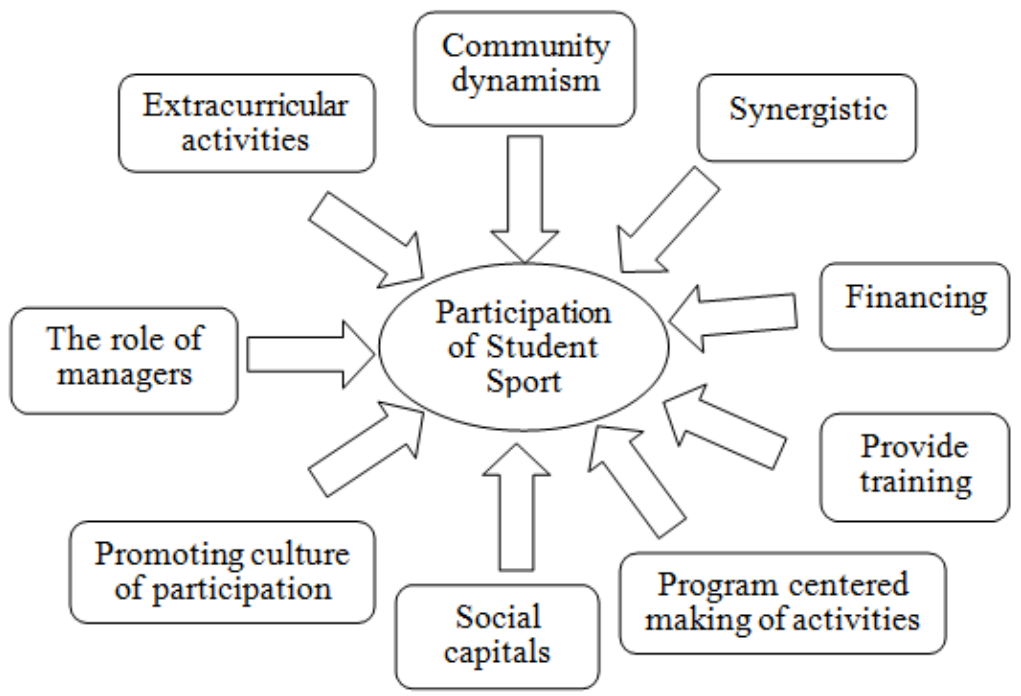

Figure 2. Identifying the underlying factors affecting the development of participation of student sport in Iran. 


\section{DISCUSSION AND CONCLUSION}

In the present study, after completing the studies, interviews, and coding, the underlying factors of intrapartial and transnational student sport development participation were identified and presented. Generally, contextual factors such as economic, social, cultural, political, structural, managerial factors influence strategies and provide the basis for attraction and development of participation. Based on the results, one of the most important underlying factors is community dynamism, which includes concepts such as creating a sense of sportsmanship, increasing student per capita activity, Establish a student health security executive team, and the effective role of student sports programs in promoting health and hygiene that indicates that guarantee the health of the whole community.As Brochado and Brito (2017) have stated, regular exercise participation has become an important part of a healthy lifestyle that benefits the mind and body of individuals. Another identified problem is synergistic that is concepts such as participatory decision making by sport managers, maximizing efficiency and effectiveness by identifying and benefiting from the capabilities of other stakeholders systems, communication and interactions for the benefit of the organization, and participation centred making on student sport activities that with the field of student sport, it can offset many shortfalls, including financial, infrastructure and specialist manpower, by creating synergies. According to interviews, student sports in the country are facing government funding constraints and a lack of educational sports facilities, and thus has limited student participation. Among the components identified for financing are the creation of legal infrastructure and a flexible structure to attract sponsors, fundraisers, marketing and increasing per capita sports space. Also, providing education to students about the importance of sport in the educational system and placing it in their mental basket through participation in verbal, written, electronic and virtual methods can promote students' participation in sports activities. On the other hand, making programcentred activities of sport field by developing strategic plans and analysing environmental conditions and developing a single code of conduct for all stakeholders of sport field can achieve their goals with less time, cost and energy. Interviews revealed that the problem of promoting social capitals, including the student as a representative of a family and society, is of particular importance, and that social capital has an interrelationship with the development of participation, and each has effect on development and progress of the other. However, Zhou and Kaplanidou (2017) stated that participation in sporting events enables the promotion of social values in society and considered the development of social capital as one of the most important social benefits of participation. Also, in the direction of cultivation, the institutionalization of sports culture among the authorities, the family and the students are taken seriously and of course the beliefs, cultures, and customs of the families are effective in the partnership. On the other hand, participation saves the country's culture and promotes social values. Accordingly, Emily Shall et al (2019) levels of participation in sports and physical activity in children are high, but in high school, participation levels decrease and are associated with sedentary behaviours. Therefore, promoting a culture of sports participation in children can provide effective public health strategies and guide children to regular physical activity. Of course, the individual and personality characteristics of managers, respect for meritocracy and the use of native managers play a decisive role in participation. Considering the educational mission of the education and the mission of heroism and talent identification of the Ministry of Sport, making a letter of understanding between these two organizations is needed in order to develop students' physical, logical and intellectual talents and leisure and extracurricular activities including talent identification of students will be united in the Olympiads and festivals and the creation of student sport clubs and student leagues in the various disciplines, and the establishment of the whole sports system with educational sports. In this regard, Stewart Villa et al. (2019) stated that one of the most popular and fun leisure time for young people in developed countries is sports participation. More than $40 \%$ of all children and adolescents participate in organized sports competitions that are even higher in high-income countries. At the end, the present study can lead to positive results and contribute to the development and promotion of student sport in the economic, cultural, social, fundamental, 
championship, health, and education fields, promoting the status of school sports and strengthening it, especially in the international arena and promotes community health and having a healthy and dynamic lifestyle, synergy of organizations and institutions to promote student sport, targeted nurturing of athletic talent, promoting sports culture, acquiring honourable sports platforms, attracting financial resources and addressing some of the financial and infrastructure problems in student sport field.

\section{REFERENCES}

Alizadeh Vali, Shahla'iJavad, Alizadeh Lili, (2016), Formulation of Safety Status of Outdoor Athletic Areas in Ardabil Province, Applied Research in Sport Management, No. 3-p:47-54.

Alkhateeb, M. (2019). Multiple Representations in 8th Grade Mathematics Textbook and the Extent to which Teachers Implement Them. International Electronic Journal of Mathematics Education, 14(1), 137-145. https://doi.org/10.12973/iejme/3982

Asefi Ahmad Ali, Amouzadeh Zahra, (2017), Modeling the Role of Important Others and Adolescent Participation in Physical Activity and Exercise, Research in Educational Exercise No. 13,. Autumn and winter of 2017. Pp17-36.

Burkely, Stan,(1996), people first a guide to self-reliant participatory Rural development. London: zedbooks.

Boekel Martin Van, BulutOkan, Stanke Luke, Palma Zamora Jose R, Jang Yoojeong, Kang Youngsoon, Nickodem Kyle, (2016) , Effects of participation in school sports on academic and social functioning, Journal of Applied Developmental Psychology, 41, p:31-40. https://doi.org/10.1016/j.appdev.2016.05.002

Brochado Oliveira, Brito Quelhas, Brochado Oliveira,(2017), Correlates of adults' participation in sport and frequency of sport, Journal Science \& Sports,P:1-9. https://doi.org/10.1016/j.scispo.2017.03.005

BanarNoushin, Dastum Salah, GoharRostami Hamid Reza, MohaddatFatemeh,(2018), Designing a Developmental Participation Model in GuilanProvince,Journal of Human Resource Management in Sport, Volume 5, Number 2, pp. 217-234.

Diorra, West; Chalers, Butcher (1995). Foundations of Physical Education and Sport. Translation: Azad, Ahmad. Tehran: Publications of the National Olympic Committee of the Islamic Republic of Iran.

Doré Isabelle, Brunet Jennifer, Gallant François,(2019), Years Participating in Sports During Childhood Predicts Mental Health in Adolescence: A 5-Year Longitudinal Study, Journal of Adolescent Health 64 (2019) 790-796. https://doi.org/10.1016/j.jadohealth.2018.11.024

FathiSoroush, (2009). Sociological Explanation of Student Sports Participation, Journal of Social Sciences, Third Year / Fourth Issue: 145-173.

Guilmette Maude. Mulvihill Kathryn. Villemaire-Krajden Rosanne. Barker Erin T,(2019),Past and present participation in extracurricular activities is associated with adaptive self-regulation of goals, academic success, and emotional wellbeing among university students, Learning and Individual Differences 73, P:8-15. https://doi.org/10.1016/j.lindif.2019.04.006

Howard Steven J, A Vella Stewart, Cliff Dylan P,(2018), Children's sports participation and selfregulation: Bi-directional longitudinal associations, journal Early Childhood Research Quarterly 42, p:140-147. https://doi.org/10.1016/j.ecresq.2017.09.006

Izadi Samad, AbediniBeltrak Moment, MansouriSirous, (2011), Content Analysis of Physical Education in Elementary Education Costs, Journal of Sport Management and Motor Behavior, Seventh Year, No. 13 , pp. $27-40$.

Javadipour, Mohammed and Samia Nina, Mona. (2013). Public sport in Iran and formulation of vision, strategy and future plans. Applied Research in Sport Management, 4, 21 - 30. 
Khalaji, Hassan (2008). Principles of physical education. Second edition, Tehran: Payam Noor University.

KeshavarzLoghman, JalaliFarahani Majid, Ansari Seyed Mohammad, (2013). Comparison of Students 'and Teachers' Attitudes toward Physical Education Teachers in Bandar Abbas Secondary School. Applied Research in Sport Management, Volume 2, Number 2, pp: 75- 84.

KhoshfarGholamreza, MohammadiArezoo, MohammadzadehFatemeh, MohammadiRazieh, AkbarzadehFatemeh, (2014), Social Security and Social Health (Case Study: Qa'en City Youth of 15-29 years), Iranian Journal of Social Studies, Volume 9, Number 1, p. : 72-102.

Lawrence O. Gostin and Eric A. Friedman,(2015), "The Sustainable Development Goals: One-Health in the World's Development Agenda," JAMA, published online December 14, 2015. https://doi.org/10.1001/jama.2015.16281

Manafi Fereidoun, RamezaniNejad Rahim, GoharRostamiHamidreza, Pourkiani Mohammad,(2014), The Impact of Infrastructure and Management Factors on the Development of Athletic Participation in Iranian Public Universities, Research in Academic Sport, No. 9, pp: 65-90.

Melekoglu Tuba ,(2015), The Effects of Sports Participation in Strength Parameters in Primary School Students, Procedia - Social and Behavioral Sciences 186 ( 2015 ) 1013 - 1018. https://doi.org/10.1016/j.sbspro.2015.04.124

Mills Kathryn, Dean Dudley, Natalie J. Collins,(2019),Do the benefits of participation in sport and exercise outweigh the negatives? An academic review, Best Practice \& Research Clinical Rheumatology,P:116. https://doi.org/10.1016/j.berh.2019.01.015

Navabakhsh Mehrdad and EsmiJoushghani Zahra, (2012), Social and Cultural Factors Affecting Student Participation in Student Activities, Iranian Journal of Social Development Studies, Fourth Year, No. 4, pp105-122.

NamaziZadeh, Mehdi. Salahshour, Bahman (2015). General Physical Education, Tehran, SAMT Publications.

Rezaian Ali, (2016), Fundamentals of Organization and Management. Publisher: Tehran University Humanities Textbooks Organization (SAMT). Humanities Research and Development Center.

Ransom Michael R, Ransom Tyler,(2018),Do high school sports build or reveal character? Bounding causal estimates of sports participation,journal Economics of Education Review,64,p:75-88. https://doi.org/10.1016/j.econedurev.2018.04.002

Straus, A. \& Corbin, J, (2008), Basic of Quapitative Research: Techniques and Procedures for developing Grounded Theory. Third Edition, Pos Angeles: stage publication. 156.

Salimi Mehdi (2017). Providing a model of professional ethics development in sports organizations. Journal of Ethics in Science and Technology, Twelfth Year, No. 1: 1-13.

Shayakhmetova, D., \&Chaklikova, A. (2018). Development of the intermediator of intercultural communication based on public argumentative speech. Opción, 34(85-2), 149-185.

Shull Emily R, Marsha Dowda, Saunders Ruth P, Mclver Kerry, Pate Russell R,(2019), Sport participation, physical activity and sedentary behavior in the transition from middle school to high school, Journal of Science and Medicine in Sport, P:1-18. https://doi.org/10.1016/j.jsams.2019.10.017

Vella Stewart A, Gardner Lauren A, Kemp Byron, Schweickle Matthew J, Cliff Dylan P,(2019), Sports Participation, Health Behaviours, and Body Fat during Childhood and Early Adolescence: A Multiple Mediation, Journal of Science and Medicine in Sport,p:1-6. https://doi.org/10.1016/j.jsams.2019.07.011

Zhou Ran, KaplanidouKyriaki ,(2017),Building social capital from sport event participation: An exploration of the social impacts of participatory sport Events on the community, Sport Management Review,P:113. https://doi.org/10.1016/i.smr.2017.11.001 


\section{(c) $)(1) \Theta(9)$}

This work is licensed under a Attribution-NonCommercial-NoDerivatives 4.0 International (CC BY-NC-ND 4.0). 